\title{
An Empirical Study on the Experience Satisfaction of Tourism Performing Arts Project under the Experience Economic Background \\ — Taking Heyuan City as an Example
}

\author{
ZHANG Ying, * \\ ${ }^{1}$ Faculty of Business Administration, Heyuan Polytechnic, Heyuan, Guangdong, 517000, China \\ *zhyxn2005@163.com
}

\begin{abstract}
High-end, efficient, and innovation driven are the keys of the tourism industry's improvement of quality and efficiency. In the experience economy age, the tourism performing arts project often is the breakthrough point of the traditional sightseeing scenic spots' transformation and development. And it's also an important means to boost the tourism industry economy, which has a comprehensive pulling effect on the tourism related industries. Including Wanlv Lake, Bavarian Manor, Mirror Flower Margin, Sujia Wai and Yellow Dragon Rock in Heyuan City, Guangdong Province, five important tourist attractions' performing arts projects are selected to construct the first level indicators such as the form, content and service of the performing arts project, and the second evaluation level indicators such as stage background, lighting effect, science and technology application, program layout, local elements, appreciate comfort.The results show that the overall satisfaction of the project is between general and the satisfactory. It is urgent to optimize system from aspects of the hardware and technology, technology application, and traffic accessibility, improving the variety and adaptability of performing arts projects to meet the practical needs of different ages, educational backgrounds, and professions. Through the integration into the Internet, we can speed up the traditional performing arts projects' planning and publicity, to realize benign docking of the supply and demand of scenic performing arts.
\end{abstract}

Keywords: Experience Economy; Tourism Performing Arts; Satisfaction; Evaluation

\section{Introduction}

According to the economic data released by the National Bureau of Statistics in 2016, China's domestic per capita GDP of 2015 was 52,000 RMB, approximately amount to about 8016 dollars; consumption in key areas continuing to show an upward trend in 2016.

In this stage of development, industrial structure in China will tilt to the services. Among them, the tourism's structural adjustment and transformation upgrading will play an important promoting role in the healthy and long-term development of the service industry[1]. The theory of experience economy is put forward by the American scholar Joseph Pine and James Gilmore in their The Experience Economy, in which the experience economy is the fourth economic develop stage. Experience is that the enterprise see service as a stage, goods or products as props, to activate the initiative of consumers from their intrinsic mental space[2]. Tourist attractions performing arts projects are not only the most basic ways for tourists to experience scenic facilities, local cultural connotations and folk customs, but also the important reflect means of the service levels of scenic, and competitiveness. Tourist attractions performing arts projects is comprehensive display projects by combining various means with the local folk customs, cultural resources and cultural performances. In the age of experience economy, the unique performing arts projects of tourist attractions are often have strong attraction to tourists, such as Changlong International Circus of the Guangzhou Changlong Group, Impression of the Third Sister Liu of Yangshuo, Guilin. Outstanding performing arts projects can improve tourist's interests and become the publicizing signboard of scenic spots,encouraging tourism and related industries to improve quality and efficiency, undertaking the supply-side reform effectively. 


\section{Overview of the Study Area}

Heyuan City is located in the northeastern of Guangdong Province. Its Hakka folk art mainly includes Hakka folk songs, Hua Chao opera, dragon dance, lion dance, spring cow dance, paper horse dance, kungfu and acrobatics. Hua Chao opera is listed in Chinese Intangible Cultural Heritage. Most of the tourist attractions performing arts of Heyuan City take Hakka culture as the carrier, bringing the Hakka cultural audio-visual experience for the visitors through the Hakka song and dance, Hakka marriage customs and other performances. Among the five tourist attractions, three scenic spots have Hakka marriage performances, namely the Mirror Flower margin tourist area, Sujia Wai Hakka rural tourism area and Yellow Dragon Rock She ethnic tourism area (see in table 1). We can see that the scenic areas have attention to the publicity of Hakka culture. In the five tourist attractions, the first full-floor earth-moving theater show in China Home-Source of Bavarian manor is in the Earthen hotel, which is an important carrier to show the Guangdong Hakka culture, is innovation masterpiece of the Guangdong scenic performing arts project. The big dragon and phoenix stage of Dragon and Phoenix island in Wanlv Lake is regrettable. Instead of characterizing Hakka, it has more magic and traditional singing and dance, has been suspended for transformation. Overall, the Heyuan City Scenic Area Project has new highlight, while the traditional scenic area remain single-type and need for transformative development urgently in order to develop the localized performing arts tourism resources better.

Table 1 Heyuan tourist attractions performing items list

\begin{tabular}{|c|c|c|c|}
\hline$\underset{r}{\text { Numbe }}$ & Name & Site & Performance Content \\
\hline 1 & $\begin{array}{l}\text { Mirror Flower } \\
\text { Margin }\end{array}$ & $\begin{array}{l}\text { Daughter Country } \\
\text { Performance Stage }\end{array}$ & $\begin{array}{l}\text { Tang dance, hakka folk song } \\
\text {, hakka marriage customs }\end{array}$ \\
\hline 2 & $\begin{array}{l}\text { Dragon and } \\
\text { Phoenix Island in } \\
\text { Wanlv Lake }\end{array}$ & $\begin{array}{l}\text { Dragon and } \\
\text { Phoenix Stage }\end{array}$ & $\begin{array}{l}\text { acrobatics, magic, traditional singing } \\
\text { and dance }\end{array}$ \\
\hline 3 & $\begin{array}{l}\text { Yellow Dragon } \\
\text { Rock She Ethnic } \\
\text { Tourism Area }\end{array}$ & $\begin{array}{l}\text { She Ethnic } \\
\text { Performance Area }\end{array}$ & $\begin{array}{c}\text { Bamboo Dance of She Ethnic } \\
\text {, hakka marriage customs }\end{array}$ \\
\hline 4 & $\begin{array}{c}\text { Sujia Wai Hakka } \\
\text { Rural Tourism Area }\end{array}$ & $\begin{array}{c}\text { Sujia Wai } \\
\text { Performance House }\end{array}$ & $\begin{array}{l}\text { Take hakka culture as the theme, } \\
\text { through dance, stage lighting effects, art } \\
\text { and technology blend, tell the story of } \\
\text { Hakka people moved from the South } \\
\text { Central Plains, looking for the hearts of } \\
\text { their homes story story. } \\
\text { hakka marriage customs, hakka folk } \\
\text { song and so on }\end{array}$ \\
\hline
\end{tabular}

\section{Methods and Significance of Study}

During the 12th Five-Year Plan period, Guangdong will focus on the three major tasks of tourism, namely reform innovation, industrial structure optimization and industrial comprehensive strength upgrading. And set building a national tourism comprehensive reform demonstration area and a strong tourism province as its development goals. The tourism industry has achieved steady growth. During the 13th Five-Year Plan period, the tourism industry of Guangdong will focus on the image of "World Leisure Tourism Destination", integrating the traditional advantage projects warm winter tourism and coastal tourism. Moreover, it will also focus on food tourism, business exhibitionism tourism, study tour tourism, parent-child tourism, rural tourism, historical tourism and others constitute the six distinctive projects. However, the tourism industry in Guangdong will also face the pressures of transformation and upgrading, supply and demand structural contradictions as the traditional tourism industry. It still needs to narrow the tourism development gap between Pearl River Delta and the eastern part of the eastern Guangdong, create regional tourism brand and establish excellent tourism talent team. This paper takes the investigation of Heyuan city tourist scenic area 
performing arts projects experience satisfaction evaluation as the carrier, aims at by our special research, using the data and facts to demonstrate the significance of developing scenic area performing arts projects to promote the transformation and upgrading of traditional scenic area and the improvement of quality and effectiveness. And it helps the healthy development of tourist attractions in Heyuan, providing helpful suggestions for the transformation and development of tourism.

\section{Study Steps \\ 4.1 Data Collection}

During the study, a comprehensive survey method combining network questionnaire with on-the-spot questionnaire survey and on-site interview was adopted. Through the field investigation of five important tourist attractions performing arts projects, such as Wanlv Lake, Bavaria Manor, Mirror Flower Margin, Sujia Wai and Yellow Dragon Rock, conducting a special investigation on the form, content and service of the performing arts project. Through statistical analysis of pertinence, collecting the information of the cultural and performing arts in the tourism project of Heyuan City and the original data of tourists' satisfaction evaluation on the experience of the performing arts projects. A total of 315 questionnaires were distributed, including 303 valid questionnaires and $96.2 \%$ of the valid ratio. Among the 303 valid questionnaires, 125 were Bavarian manor, 106 were Mirror Flower Margin, 25 were Dragon and Phoenix island in Wanlv Lake, 24 were Sujia Wai Hakka Village Tourism Area and 23 were Yellow Dragon Rock She Nationality Tourist Area (see in Table 2).

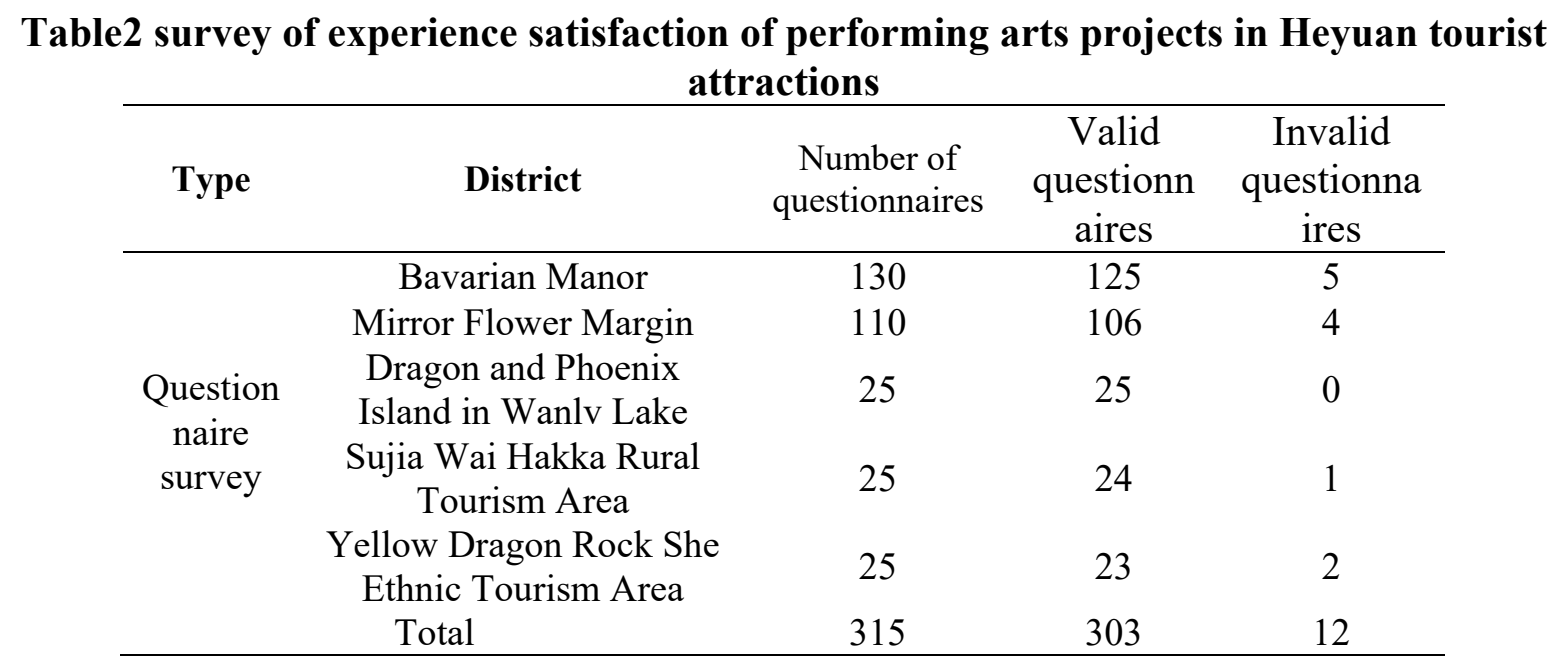

\subsection{Data Analysis}

The authenticity of tourist perception is essential to the experience of tourism performance. The real scene, character image, cultural accumulation and so on, all have positive impact on the formation of a good experience[3]. So we use the Likert scale method to establish 5 evaluation levels(very dissatisfied with 1 points, dissatisfied with 2 points, general with 3 points, satisfied with 4 points, very satisfied with 5 points). We also construct an overall satisfaction index and 15 secondary indicators such as stage background, lighting effects, costume features, dance choreography, music effects, science and technology application, local elements, performance theme, cultural connotation, time arrangement, space environment, traffic conditions, convenience, enjoy comfort and harmony of the scenic environment, and so on, in order to evaluate and analyze the satisfaction of performing arts project. The results showed that the tourists' satisfaction was between 3.52 and 3.96, which was between the general and the satisfaction. The overall satisfaction rating is 3.84 , that is, the general, failed to achieve satisfaction; in the sub-projects evaluation, the highest local elements of 3.96, the lowest technology application of 3.52 . 
Table 3 evaluation analysis of satisfaction of Performing Arts Projects in Heyuan tourist attractions

\begin{tabular}{|c|c|c|c|c|c|c|}
\hline Evaluation indicator & 1 oint & 2 points & 3 points & 4 points & 5 points & $\begin{array}{c}\text { Average } \\
\text { score }\end{array}$ \\
\hline $\begin{array}{l}\text { A1.Tourism Performing } \\
\text { Arts form: } \\
\text { stage background }\end{array}$ & $\begin{array}{l}3.96 \% \\
12\end{array}$ & $\begin{array}{c}7.92 \% \\
24\end{array}$ & $\begin{array}{c}30.03 \% \\
91\end{array}$ & $\begin{array}{c}31.68 \% \\
96\end{array}$ & $\begin{array}{c}26.40 \% \\
80\end{array}$ & 3.69 \\
\hline $\begin{array}{l}\text { A2. Tourism Performing } \\
\text { Arts form: } \\
\text { lighting effects }\end{array}$ & $\begin{array}{l}3.30 \% \\
10\end{array}$ & $\begin{array}{c}11.88 \% \\
36\end{array}$ & $\begin{array}{c}33.99 \% \\
103\end{array}$ & $\begin{array}{c}30.36 \% \\
92\end{array}$ & $\begin{array}{c}20.46 \% \\
62\end{array}$ & 3.53 \\
\hline $\begin{array}{l}\text { A3. Tourism Performing } \\
\text { Arts form: } \\
\text { costume features }\end{array}$ & $\begin{array}{c}2.64 \% \\
8\end{array}$ & $\begin{array}{c}3.96 \% \\
12\end{array}$ & $\begin{array}{c}23.10 \% \\
70\end{array}$ & $\begin{array}{c}43.89 \% \\
133\end{array}$ & $\begin{array}{c}26.40 \% \\
80\end{array}$ & 3.87 \\
\hline $\begin{array}{l}\text { A4.Tourism Performing } \\
\text { Arts form: } \\
\text { dance choreography }\end{array}$ & $\begin{array}{c}3.30 \% \\
10\end{array}$ & $\begin{array}{c}4.62 \% \\
14\end{array}$ & $\begin{array}{c}30.36 \% \\
92\end{array}$ & $\begin{array}{l}38.94 \% \\
118\end{array}$ & $\begin{array}{c}22.77 \% \\
69\end{array}$ & 3.73 \\
\hline $\begin{array}{l}\text { A5.Tourism Performing } \\
\text { Arts form: } \\
\text { music effects }\end{array}$ & $\begin{array}{c}2.64 \% \\
8\end{array}$ & $\begin{array}{c}7.59 \% \\
23\end{array}$ & $\begin{array}{l}28.05 \% \\
85\end{array}$ & $\begin{array}{l}37.95 \% \\
115\end{array}$ & $\begin{array}{c}23.76 \% \\
72\end{array}$ & 3.73 \\
\hline $\begin{array}{l}\text { A6. Tourism Performing } \\
\text { Arts form: } \\
\text { science and technology } \\
\text { application }\end{array}$ & $\begin{array}{c}4.62 \% \\
14\end{array}$ & $\begin{array}{c}17.16 \% \\
52\end{array}$ & $\begin{array}{c}28.38 \% \\
86\end{array}$ & $\begin{array}{l}21.12 \% \\
64\end{array}$ & $\begin{array}{c}28.71 \% \\
87\end{array}$ & 3.52 \\
\hline $\begin{array}{l}\text { B1.Tourism Performing } \\
\text { Arts content: } \\
\text { local elements }\end{array}$ & $\begin{array}{c}2.64 \% \\
8\end{array}$ & $\begin{array}{c}2.97 \% \\
9\end{array}$ & $\begin{array}{c}21.12 \% \\
64\end{array}$ & $\begin{array}{c}41.91 \% \\
127\end{array}$ & $\begin{array}{c}31.35 \% \\
95\end{array}$ & 3.96 \\
\hline $\begin{array}{l}\text { B2. Tourism Performing } \\
\text { Arts content: } \\
\text { performance theme }\end{array}$ & $\begin{array}{l}3.30 \% \\
10\end{array}$ & $\begin{array}{c}3.30 \% \\
10\end{array}$ & $\begin{array}{c}27.39 \% \\
83\end{array}$ & $\begin{array}{l}40.59 \% \\
123\end{array}$ & $\begin{array}{c}25.41 \% \\
77\end{array}$ & 3.82 \\
\hline $\begin{array}{l}\text { B3. Tourism Performing } \\
\text { Arts content: } \\
\text { cultural connotation }\end{array}$ & $\begin{array}{c}3.30 \% \\
10\end{array}$ & $\begin{array}{c}3.96 \% \\
12\end{array}$ & $\begin{array}{c}23.43 \% \\
71\end{array}$ & $\begin{array}{c}43.56 \% \\
132\end{array}$ & $\begin{array}{c}25.74 \% \\
78\end{array}$ & 3.84 \\
\hline $\begin{array}{l}\text { C1.Tourism Performing } \\
\text { Arts service: } \\
\text { time arrangement }\end{array}$ & $\begin{array}{l}2.97 \% \\
9\end{array}$ & $\begin{array}{c}4.29 \% \\
13\end{array}$ & $\begin{array}{c}28.71 \% \\
87\end{array}$ & $\begin{array}{c}39.60 \% \\
120\end{array}$ & $\begin{array}{c}24.42 \% \\
74\end{array}$ & 3.78 \\
\hline $\begin{array}{l}\text { C2.Tourism Performing } \\
\text { Arts service: } \\
\text { space environment }\end{array}$ & $\begin{array}{c}2.64 \% \\
8\end{array}$ & $\begin{array}{l}6.27 \% \\
19\end{array}$ & $\begin{array}{c}27.06 \% \\
82\end{array}$ & $\begin{array}{l}39.60 \% \\
120\end{array}$ & $\begin{array}{c}24.42 \% \\
74\end{array}$ & 3.77 \\
\hline $\begin{array}{l}\text { C3. Tourism Performing } \\
\text { Arts service: } \\
\text { traffic conditions }\end{array}$ & $\begin{array}{l}3.30 \% \\
10\end{array}$ & $\begin{array}{c}6.27 \% \\
19\end{array}$ & $\begin{array}{c}34.32 \% \\
104\end{array}$ & $\begin{array}{c}35.31 \% \\
107\end{array}$ & $\begin{array}{c}20.79 \% \\
63\end{array}$ & 3.64 \\
\hline $\begin{array}{c}\text { C4. Tourism Performing } \\
\text { Arts service: } \\
\text { convenience }\end{array}$ & $\begin{array}{l}2.97 \% \\
9\end{array}$ & $\begin{array}{c}2.31 \% \\
7\end{array}$ & $\begin{array}{c}30.03 \% \\
91\end{array}$ & $\begin{array}{l}41.58 \% \\
126\end{array}$ & $\begin{array}{c}23.10 \% \\
70\end{array}$ & 3.8 \\
\hline $\begin{array}{c}\text { C5.Tourism Performing } \\
\text { Arts service: } \\
\text { enjoy comfort }\end{array}$ & $\begin{array}{l}3.30 \% \\
10\end{array}$ & $\begin{array}{l}5.61 \% \\
17\end{array}$ & $\begin{array}{c}27.39 \% \\
83\end{array}$ & $\begin{array}{l}40.26 \% \\
122\end{array}$ & $\begin{array}{c}23.43 \% \\
71\end{array}$ & 3.75 \\
\hline $\begin{array}{l}\text { C6. Tourism Performing } \\
\text { Arts service: } \\
\text { harmony of the scenic } \\
\text { environment }\end{array}$ & $\begin{array}{l}2.97 \% \\
9\end{array}$ & $\begin{array}{l}2.97 \% \\
9\end{array}$ & $\begin{array}{c}21.78 \% \\
66\end{array}$ & $\begin{array}{c}43.89 \% \\
133\end{array}$ & $\begin{array}{c}28.38 \% \\
86\end{array}$ & 3.92 \\
\hline $\begin{array}{l}\text { D.overall satisfaction } \\
\text { index }\end{array}$ & $\begin{array}{c}3.96 \% \\
12\end{array}$ & $\begin{array}{c}1.98 \% \\
6\end{array}$ & $\begin{array}{l}25.41 \% \\
77\end{array}$ & $\begin{array}{c}43.23 \% \\
131\end{array}$ & $\begin{array}{c}25.41 \% \\
77\end{array}$ & 3.84 \\
\hline
\end{tabular}

Number of effective evaluation samples : 303 


\section{Conclusion and Discussion}

The transformation of the tourism industry includes external and internal changes. External changes are often caused by the transition of the economic system. The internal changes mainly refer to the transformation of the industrial development mode caused by the transformation of tourism consumption [4]. Industrial transformative upgrading and the improvement of quality and efficiency is the trend. Tourism industry needs develop towards green, high-quality, high value-added direction. Only by this, it can really promote economic and social development. Heyuan City is one of the outstanding tourism cities and eco-tourism destination cities in China, and its tourism is one of the important pillar industries of China's national economy. Tourism industry's transformation and upgrading, and its improvement of quality and effectiveness is urgently needed. As an important component of Heyuan tourism industry, tourism scenic areas' developing level and operational status have significant impact. After the evaluation study, the overall satisfaction of the project is between the general and the satisfied. It's urgent to optimize the project from the aspects of hardware, technology application, traffic accessibility and management quality improvement. We should improve the variety and adaptability of performing arts projects to meet the different age, education, and professions' practical needs. First of all, cultural performing arts projects, should be more use of local cultural resources, both for the performance into the cultural soul, but also help Heyuan city branding and urban cultural propaganda; Secondly, the area should update travel information such as performing arts and performance information, so that visitors can check; Thirdly, we must pay attention to integration into the Internet platform, strengthening publicity and planning to the ancillary products of the performing arts, tourism products, accommodation conditions, scenic traffic links, tourism traffic signs and other aspects; enhancing the construction of network marketing platform(such as WeChat, etc.) ; Finally, we should identify the contact point of performing arts market's supply and demand, and do the scenic performing arts project booking management and content updating well.

\section{Acknowledgement}

The author would like to thank support of National Tourism Administration the "Thousands of Tourism Talents" research project In 2016(No.:WMYC20164-1144), Philosophy and Social Sciences in Heyuan, "13th Five-Year" planning project (No. : HYSK16Z02),Heyuan Polytechnic research project (No. : 2014KJ06).

\section{References}

[1] Su Jian. Look at the supply side reform from the upgrading of high-end services [J]. China Finance, 2016, (1):33-34.

[2] Wu Wenzhi, Zhuang Zhimin. Design and innovation of tourism products in the age of experience economy -- take experience exploitation of ancient village tourism product as an example [J]. Tourism Tribune, 2003, 18 (6): 66-70.

[3] Zou Tongqian, Wu Liyun. The essence, types and creating principles of tourism experience[J]. Tourism Science, 2003, 17 (4): 7-10.

[4] Xu Wenyan. Tourism service innovation and transformation of tourism industry [J]. Journal of Nanjing University of Finances and Economics, 2010 (2): 34-38. 